\title{
INVESTIGATION OF THE ROLE OF POD ABNORMALITY INCIDENCE ON YIELD AND YIELD COMPONENTS OF SOYBEAN (A CASE STUDY IN GOLESTAN PROVINCE, IRAN)
}

\author{
SOUKHTEHSARAEI, M. ${ }^{1}$ - DADASHI, M. R..$^{1 *}$ - FARAJI, A. ${ }^{2}-$ SOLTANI, A. ${ }^{3}$ \\ ${ }^{I}$ Department of Agronomy, Gorgan Branch, Islamic Azad University, Gorgan, Iran \\ ${ }^{2}$ Horticulture and Agronomy Department, Golestan Agricultural and Natural Resources \\ Research and Education Center, Agricultural Research, Education and Extension Organization \\ (AREEO), Gorgan, Iran \\ ${ }^{3}$ Department of Agronomy and Plant Breeding, Gorgan University of Agricultural Sciences and \\ Natural Resources, Gorgan, Iran \\ *Corresponding author \\ e-mail:mdadashi730@yahoo.com \\ (Received 29 $9^{\text {th }}$ Jul 2018; accepted $8^{\text {th }}$ Oct 2018)
}

\begin{abstract}
The differences between theoretical yield levels and farmers' actual yields define the yield gaps. Soybean is an important global commodity. Therefore, the present study was performed to investigate of the role of pod abnormality incidence on yield and yield components of soybean in Aliabad Katul, Golestan Province, Iran. During the growing season of soybean cultivation (2016-17), 120 farms were selected with a different range of conditions and crop management, soil characteristics, and planting date. Selected farms were at a maximum radius of $10 \mathrm{~km}$ from the meteorological station. Abnormality percent (dysfunction syndrome in the R3 stage of soybean growth), yield and yield components, and seed oil and protein contents were evaluated at the end of the experiment. The results of simple correlation coefficients showed that there was a significant and positive correlation between yield and yield components as well as seed oil content. According to the analysis of regression, there was a significant effect of abnormality percent (as the dependent variable) on yield and yield components (as independent variables) except number of pods with one seed and seed protein content. The improvement of morphological and yielding traits resulted in a reduction in the abnormality percent. In some cases, the damage of pod abnormality caused 30\% reduction in grain yield. In general, among environmental and agronomic factors, the number of days with temperature higher than $25{ }^{\circ} \mathrm{C}$ at flowering stage $(5$ days before and 10 days after flowering $=\mathrm{R} 3$ growth stage of soybean) had a significantly positive correlation with the abnormality percent. It can be concluded that crop management such as suitable planting date, cultivation of tolerant genotype, irrigation management especially at flowering stage, nutrition management, and others, can reduce the severity of the abnormality percent.
\end{abstract}

Keywords: crop management, dysfunction syndrome, environmental stress, Glycine max L. regression analysis, yield gap

\section{Introduction}

Soybean (Glycine max (L.) Merr.) seeds have high levels of protein (38-40\%), oil $(18-20 \%)$ and are broadly utilized by the food industry as either raw or processed forms of various soy products (Carvalho et al., 2017). Also, this plant is one of the most important legume crops which fix the atmospheric nitrogen in symbiotic association with bacteria through nodules (Ospanbayev et al., 2017). For soybean, dry matter derived from leaf photosynthesis constitutes over $90 \%$ of overall dry matter accumulation and is considered a determinant of yield (Zhang et al., 2016). The crop is a major contributor to the world's food supply (Kumagai and Sameshima, 2014). 
Growth, development, and soybean yield depend on the genetic potential of a cultivar and its interaction with the environment. In a field situation, nature provides the major portion of the environmental influence on soybean development and yield, however, soybean producers can manipulate this environment with proven managerial practices (Van Roekel et al., 2015; Firake et al., 2016). Also, yields of crops must increase substantially over the coming decades to keep pace with global food demand driven by population and income growth (Ittersum et al., 2013). Quantifying food production capacity on every hectare of current farmland in a consistent and transparent manner is needed to inform decisions on policy, research, development, investment that aim to affect future crop yield and land use, and to inform on-ground action by local farmers through their knowledge networks (Ittersum et al., 2013).

The differences between these theoretical yield levels and actual farmers' yields define the yield gaps, and precise spatially explicit knowledge about these yield gaps is essential to guide sustainable intensification of agriculture (Licker et al., 2010). Sentelhas et al. (2015) evaluated the soybean yield gap in Brazil; the results showed that the main part of the yield gap was caused by water deficit, followed by sub-optimal crop management, the results demonstrated that irrigation, crop rotation, and precision agriculture, improved dissemination of agricultural knowledge and the use of crop simulation models as a tool for improving crop management could further contribute to reducing the Brazilian soybean yield gap.

Unfortunately, in recent years, climate change has increased the temperature especially at the time of reproductive growth and flowering stages of soybean, which has caused physiological changes in the plant (Thuzar et al., 2010). These changes lead to disruptions in the flower and pod systems, which eventually leads to a lack of productivity, low productivity, and the so-called by farmers become forage of soybean and in the scientific term, dysfunction syndrome in R3 stage of soybean growth (Beginning pod development) or abnormality pod percent (Faraji and Raessi, 2015). This phenomenon is unknown in the world. Such conditions, reproductive and vegetative growths conflicts with each other. If the conditions for the growth of secondary pod and seed are favorable, this phenomenon is partly restored. Otherwise, if the environmental conditions are not allowed during the autumn period, the leaf and pod remain green. In other words, in the dysfunction syndrome, a mechanism prevents the transfer of photosynthetic material from the leaf to grain. The leaves remained green and the grain maturity is difficult. Figure 1 shows the dysfunction syndrome of soybean in Golestan Province of Iran. The cultivation area and the rate of dysfunction syndrome damages in the farms of Golestan Province of Iran during 2007 to 2015 are presented in Table 1 (Technical report of Golestan Agricultural Jihad Organization, 2016).

It seems that in the suffering plants, a factor has caused severe flowering downfall and the plant are trying to compensate for re-flowering. The time of the formation of reflowers is usually early in October months, and the flowers and pods do not opportunities for development. The pods may remain imperfect or fall off. Sometimes seen as a piece of a farm with single management segments or strips of it is dysfunction syndrome, the issue of access to reason, how and why it is difficult (Faraji and Raessi, 2015). Rahimian et al. (1995) suggested the presence of TBV (TRSV), TmRSV and Stearic Tobacco (TSV) viruses which could be one of the reasons for this dysfunction. An investigation of the pollen grain number on stigma by Ohnishi et al. (2010) suggests that insufficient pollination causes low pod set under low- temperature stress at temperature- sensitive stages (12.5 and 3 days before the anthesis). 
In 2011 and 2015 years, about 18 and 39 percent respectively, of the farms in Golestan Province suffered from this dysfunction (Table 1). The severity of the occurrence of the dysfunction in the past years has raised concerns about the impact on farmers' incomes and caused various challenges for the development of this plant. The aim of this study was to investigate the correlation between yield and yield components as well as regression relations between them and dysfunction syndrome in farms of Golestan Province of Iran.

Table 1. The cultivation area and the rate of dysfunction syndrome damages (abnormality percent) in the farms of Golestan Province, Iran during 2007 up to 2015

\begin{tabular}{c|c|c|c|c|c|c|c|c|c}
\hline Years & $\mathbf{2 0 0 7}$ & $\mathbf{2 0 0 8}$ & $\mathbf{2 0 0 9}$ & $\mathbf{2 0 1 0}$ & $\mathbf{2 0 1 1}$ & $\mathbf{2 0 1 2}$ & $\mathbf{2 0 1 3}$ & $\mathbf{2 0 1 4}$ & $\mathbf{2 0 1 5}$ \\
\hline $\begin{array}{c}\text { Cultivation } \\
\text { area (ha) }\end{array}$ & 54859 & 56200 & 54108 & 58342 & 57669 & 53405 & 45352 & 52000 & 35107 \\
\hline $\begin{array}{c}\text { Damages rate } \\
\text { (ha) }\end{array}$ & 20190 & 176 & Negligible & Negligible & 10386 & 1623 & Negligible & Negligible & 13765 \\
\hline $\begin{array}{c}\text { Damages } \\
\text { percent (\%) }\end{array}$ & 4 & 3 & Negligible & Negligible & 18 & 3 & Negligible & Negligible & 39 \\
\hline $\begin{array}{c}\text { Yield } \\
\text { thousand } \\
\text { tons) }\end{array}$ & 122 & 120 & 121 & 120 & 82 & 115 & 95 & 94 & 60 \\
\hline
\end{tabular}
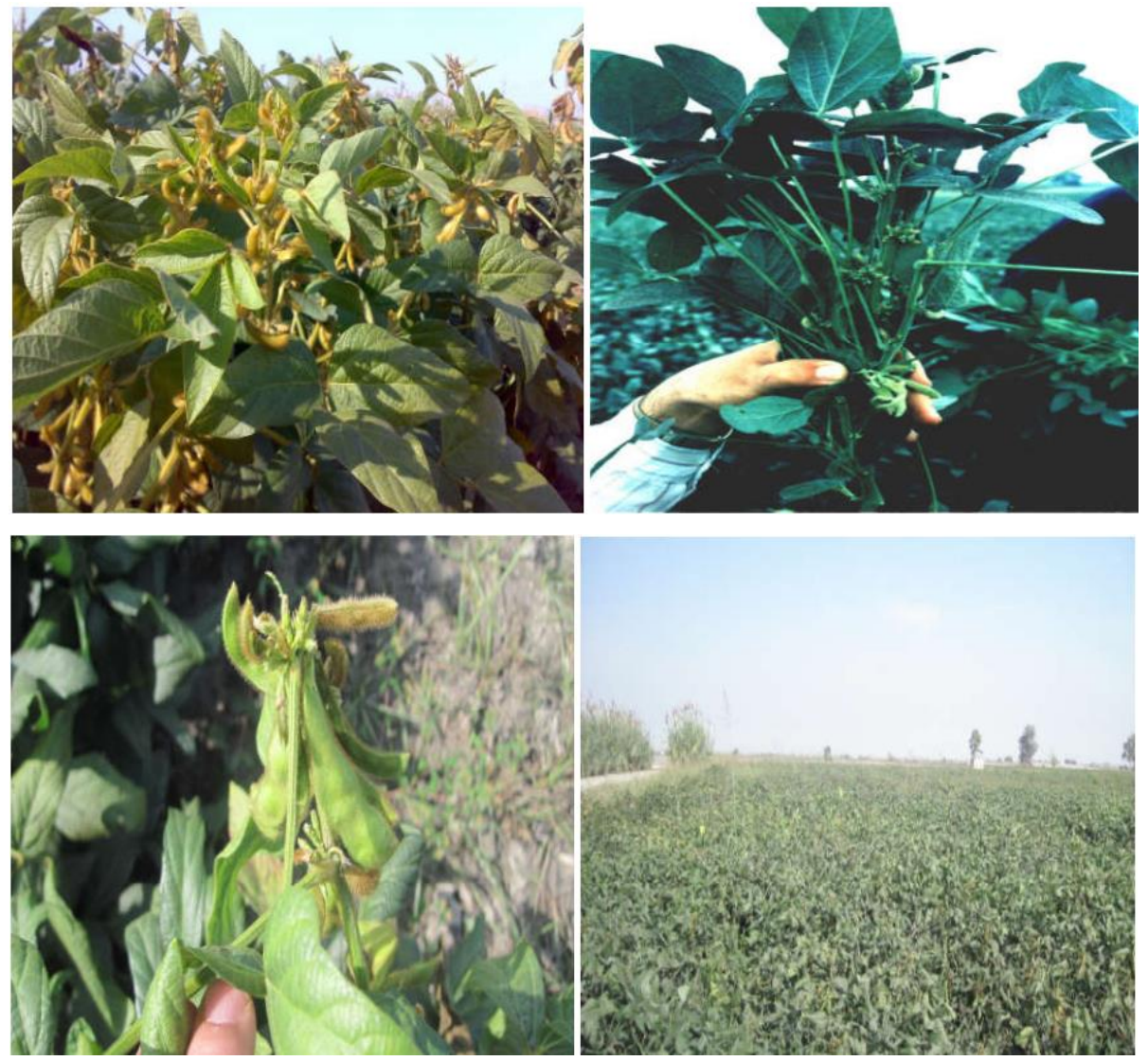

Figure 1. Dysfunction syndrome of soybean during R3 stage (beginning pod development) in Golestan Province of Iran (Faraji and Raessi, 2015) 


\section{Material and methods}

This experiment was performed to the investigate factors affecting soybean yield gap and dysfunction syndrome rate in Aliabad Katul, Golestan Province, Iran (36 54'30" N $54^{\circ} 52^{\prime} 08^{\prime \prime}$ E) in 2016-17 cropping year. During the growing season of soybean cultivation, 120 farms were selected with the different range of conditions and crop management, soil characteristics and planting date. Selected farms were at a maximum radius of $10 \mathrm{~km}$ from the meteorological station. During the growing season, information was collected such as geographical location, planting date, plant density, previous planting in the crop rotation, soil characteristics, soil tillage, type and amount of fertilizer, number, and date of irrigation, type and time of consumed insecticide and herbicides (data not presented). The average meteorological information for cropping year and long-term were presented in Tables 2 and 3.

In the field studies, the number of pods (number of pods without grain and one, two, three, and four grains) and other traits related to yield and yield components including grain number in pods, number of seeds per plant, 100-seed weight, grain yield, biological yield, and harvest index (seed yield to biological yield $\times 100$ ) in the R7 stage were investigated (Bezerra et al., 2016; Saryoko et al., 2017). For this purpose, we used the quadrat sampling method $(0.5 \times 0.5 \mathrm{~m})$. Five times random sampling was done from each farm. Then, 10 samples (plant) in 3 replications from each experimental farm were randomly selected and the traits mentioned were measured (Lamastus and Shaw, 2005). All pods in the tagged plants were counted and the average number of pods per plant was determined. Plants were dried in an oven at $100{ }^{\circ} \mathrm{C}$ for $24 \mathrm{hs}$ and after that taken and immediately weighed, and the average weight of dry plant was determined. All seeds were counted, and the average number of seeds per plant was determined. The number of seeds per pod was counted by using the following formula: number of seeds/pod $=$ number of seeds/plant $\div$ number of pods/plant. 100 seeds, were taken randomly from the tagged plants of each plot then weighed in sensitive balance to determine 100 seeds weight for each treatment. A meter length from the middle ridge of each plot was harvested and immediately weighed to determine green yield and then transferred to $\mathrm{kg} / \mathrm{ha}$. The same meter length was dried in an oven at $100{ }^{\circ} \mathrm{C}$ for $24 \mathrm{~h}$ and after that taken and immediately weighed to determine biological yield, then it was transferred to $\mathrm{kg} / \mathrm{ha}$. Seeds in the same meter length from each plot were collected and dried naturally by the sun for a week, then cleaned and weighed in sensitive balance to determine seeds yield, and transferred to $\mathrm{kg} / \mathrm{ha}$. Harvest index was calculated by the following: harvest index $=$ seed yield $\div$ biological yield $\times 100$ (Yagoub et al., 2012). By counting the number of abnormality pods and dividing them into the number of normal pods, the abnormality percentage was calculated.

Seed oil and protein contents were conducted with three replications for each farm. Oil concentration was determined as described by Pipolo et al. (2004). Ground seeds were weighed into pre-weighed test tubes and covered with $5 \mathrm{ml}$ of hexane: methyltert butyl ether solvent (1:1). The mixture was vortexed for $2 \mathrm{~min}$ and left overnight at $25^{\circ} \mathrm{C}$. The tubes were vortexed again and then centrifuged for $10 \mathrm{~min}$ at $300 \mathrm{~g}$. Much of the solvent was removed with a Pasteur pipette, followed by the addition of more solvent to the partially defatted powder. This process was repeated three times but the second and third extractions were incubated in the solvent for $4 \mathrm{~h}$. Following the third extraction, the solvent remaining after pipetting was evaporated by flowing $\mathrm{N}_{2}$ over the powder heated to $45{ }^{\circ} \mathrm{C}$. The oil content was determined as the difference in weight between the initial sample and the powder remaining after extraction. For nitrogen 
analysis, the powder remaining in each flask after oil extraction was analyzed using the Kjeldahl procedure. The sample was digested using a modification of the aluminum block digestion procedure of Gallaher et al. (1975). The catalyst was $1.5 \mathrm{~g}$ of 9:1 $\mathrm{K}_{2} \mathrm{SO}_{4}: \mathrm{CuSO}_{4}$ and digestion were conducted for at least $4 \mathrm{~h}$ at $375{ }^{\circ} \mathrm{C}$ using $6 \mathrm{ml}$ of $\mathrm{H}_{2} \mathrm{SO}_{4}$ and $2 \mathrm{ml} \mathrm{H}_{2} \mathrm{O}_{2}$. Nitrogen in the digestate was determined by semi-automated colorimetry (Hambleton, 1977) and protein concentration was calculated by multiplying by 6.25 . The protein content was determined as the amount of protein in the initial sample. Oil and protein concentrations were normalized within each experiment against the values obtained with the $60 \mathrm{mM}$ of glutamine treatment in each experiment.

Data were summarized and tested if they follow a Gaussian model (normal distribution) using Shapiro-Wilk test (5\% of probability) and homogeneity of variances between groups and within groups, using the Levene test (5\% of probability). Correlation matrices regression analysis were also performed. All analysis was performed in SAS ver. 9.2 software. Microsoft Excel 2013 was used to draw graphs.

Table 2. The mean weather conditions for fields of study in cropping year 2016-17

\begin{tabular}{c|c|c|c|c|c|c|c|c|c|c|c|c}
\hline Parameters & Apr & May & Jun & Jul & Aug & Sep & Oct & Nov & Dec & Jan & Feb & Mar \\
\hline $\begin{array}{c}\text { Temperature } \\
\left({ }^{\circ} \mathrm{C}\right)\end{array}$ & 14.9 & 21.4 & 25.2 & 28.5 & 28.6 & 26.5 & 19.4 & 13.9 & 08.1 & 08.2 & 06.4 & 11.0 \\
\hline $\begin{array}{c}\text { Maximum relative } \\
\text { humidity (\%) }\end{array}$ & 092 & 094 & 089 & 085 & 083 & 084 & 089 & 094 & 091 & 088 & 093 & 093 \\
\hline $\begin{array}{c}\text { Minimum relative } \\
\text { humidity (\%) }\end{array}$ & 062 & 055 & 048 & 044 & 042 & 044 & 053 & 060 & 055 & 056 & 063 & 057 \\
\hline $\begin{array}{c}\text { Rainfall } \\
\text { (mm) }\end{array}$ & 147.4 & 46.6 & 30.5 & 22.2 & 31.3 & 68.9 & 36.2 & 73.0 & 53.6 & 06.7 & 100.3 & 44.1 \\
\hline $\begin{array}{c}\text { Total number of } \\
\text { rainy days }\end{array}$ & 16 & 14 & 07 & 08 & 06 & 08 & 07 & 09 & 13 & 05 & 18 & 09 \\
\hline $\begin{array}{c}\text { Evaporation total } \\
\text { (mm) }\end{array}$ & 72.4 & 145.3 & 191.4 & 198.8 & 231.0 & 183.7 & 109.8 & 64.6 & 53.4 & 41.3 & 29.9 & 64.0 \\
\hline $\begin{array}{c}\text { Wind speed } \\
\text { (m/s) }\end{array}$ & 22 & 21 & 17 & 11 & 17 & 14 & 10 & 26 & 22 & 11 & 15 & 16 \\
\hline
\end{tabular}

Table 3. Long-term averages meteorological conditions of the examined area

\begin{tabular}{c|c|c|c|c|c|c|c|c|c|c}
\hline \multicolumn{3}{c|}{ Temperature $\left({ }^{\circ} \mathbf{C}\right)$} & \multicolumn{3}{|c|}{ Relative Humidity $(\%)$} & \multirow{2}{*}{$\begin{array}{c}\text { Rain } \\
(\mathbf{m m})\end{array}$} & $\begin{array}{c}\text { Sunshine } \\
(\mathbf{h})\end{array}$ & $\begin{array}{l}\text { Evap. } \\
(\mathbf{m m})\end{array}$ & \multicolumn{2}{|c}{ Wind (m/s) } \\
\hline Min. & Max. & Min & Min. & Max. & Min & & FF \\
\hline 12.5 & 23.2 & 17.9 & 33 & 87 & 60 & 01.9 & 05.8 & 03.4 & 236.6 & 05.4 \\
\hline
\end{tabular}

\section{Results}

\section{Correlation matrix among the morphological and yielding traits}

When data were correlated (Pearson correlation) to see if there are an association between the variables, these results were indicated in Table 4. Grain yield was positively correlated with number of pods with two seeds, number of pods with three seeds, number of healthy pods in main branch, number of healthy pods in lateral branch, 
total healthy pods per plant, number of seeds per pod, number of seeds per plant, 100seed weight, biological yield, harvest index, and seed oil content $(\mathrm{r}=0.73,0.65,0.64$, $0.51,0.67,0.70,0.72,0.67,0.91,0.91$, and 0.46 , respectively) and negatively correlated with total unhealthy pods and abnormality percent $(r=-0.69$ and -0.90 , respectively).

A negative correlation of abnormality percent with number of pods with two seeds, number of pods with three seeds, number of healthy pods in main branch, number of healthy pods in lateral branch, total healthy pods per plant, number of seeds per pod, number of seeds per plant, 100-seed weight, biological yield, harvest index, and seed oil content was found $(\mathrm{r}=-0.70,-0.60,-0.59,-0.48,-0.63,-0.76,-0.68,-0.68,-0.90,-0.78$, -0.92 , and -0.50 , respectively). The high positive correlation was also found between abnormality percent with total unhealthy pods per plant $(\mathrm{r}=0.81)$.

Table 4. Correlation coefficients yield and yield component attributes of soybean

\begin{tabular}{|c|c|c|c|c|c|c|c|c|c|c|c|c|c|c|c|c|}
\hline & 1 & 2 & 3 & 4 & 5 & 6 & 7 & 8 & 9 & 10 & 11 & 12 & 13 & 14 & 15 & 16 \\
\hline 1 & 1 & & & & & & & & & & & & & & & \\
\hline 2 & $0.33^{* *}$ & 1 & & & & & & & & & & & & & & \\
\hline 3 & & $0.71^{* *}$ & 1 & & & & & & & & & & & & & \\
\hline 4 & & & $0.31 * *$ & 1 & & & & & & & & & & & & \\
\hline 5 & $0.31 * *$ & $0.66^{*}$ & $0.58^{* *}$ & $0.20^{*}$ & 1 & & & & & & & & & & & \\
\hline 6 & $0.38^{* *}$ & $0.83^{* *}$ & $0.72 * *$ & $0.21^{*}$ & $0.33^{* *}$ & 1 & & & & & & & & & & \\
\hline 7 & $0.41^{* *}$ & $0.91^{* *}$ & $0.81^{* *}$ & $0.26^{*}$ & $0.71 * *$ & $0.89 * *$ & 1 & & & & & & & & & \\
\hline 8 & & $-0.57 * *$ & $-0.49 * *$ & & -0.50 ** & $-0.36^{* *}$ & $-0.51 * *$ & 1 & & & & & & & & \\
\hline 9 & $-0.42 * *$ & $0.49^{* *}$ & $0.74 * *$ & $0.28^{*}$ & $0.40^{* *}$ & $0.38^{* *}$ & $0.48^{* * *}$ & $-0.71 * *$ & 1 & & & & & & & \\
\hline 10 & $0.22 *$ & $0.90^{* *}$ & $0.92 * *$ & $0.31 * *$ & $0.68 * *$ & $0.85^{* *}$ & $0.95^{* * *}$ & $-0.54 * *$ & $0.64 * *$ & 1 & & & & & & \\
\hline 11 & & $0.55^{* *}$ & $0.43^{* *}$ & & $0.48^{* *}$ & $0.39 * *$ & $0.51^{* *}$ & $-0.61 * *$ & $0.44 * *$ & $0.50 * *$ & 1 & & & & & \\
\hline 12 & & $0.73^{* *}$ & $0.65^{* *}$ & & $0.64 * *$ & $0.51 * *$ & $0.67 * *$ & $-0.69 * *$ & $0.70^{* * *}$ & $0.72 * *$ & $0.67 * *$ & 1 & & & & \\
\hline 13 & & $0.71^{* *}$ & $0.64^{* *}$ & & $0.61 * *$ & $0.52 * *$ & $0.66^{* *}$ & $-0.63 * *$ & $0.62 * *$ & $0.71 * *$ & $0.68 * *$ & $0.91 * *$ & 1 & & & \\
\hline 14 & & $0.62 * *$ & $0.56^{* *}$ & & $0.56^{* * *}$ & $0.42 * *$ & $0.57^{* * *}$ & $-0.69 * *$ & $0.69 * *$ & $0.62 * *$ & $0.59 * *$ & $0.91 * *$ & $0.72 * *$ & 1 & & \\
\hline 15 & & $0.40^{* *}$ & $0.45^{* *}$ & & $0.21^{*}$ & $0.34 * *$ & $0.35^{* *}$ & $-0.56 * *$ & $0.49 * *$ & $0.43 * *$ & $0.34 * *$ & $0.46^{* *}$ & $0.44 * *$ & $0.43 * *$ & 1 & \\
\hline 16 & & & & & & & & & & & & & & & $-0.25 *$ & \\
\hline 17 & & $-0.70 * *$ & $-0.60 * *$ & & $-0.59 * *$ & $-0.48 * *$ & $-0.63 * *$ & $0.81^{* * *}$ & $-0.76 * *$ & $-0.68 * *$ & $-0.68 * *$ & $-0.90^{* *}$ & $-0.78 * *$ & $-0.92 * *$ & $-0.50 * *$ & \\
\hline
\end{tabular}

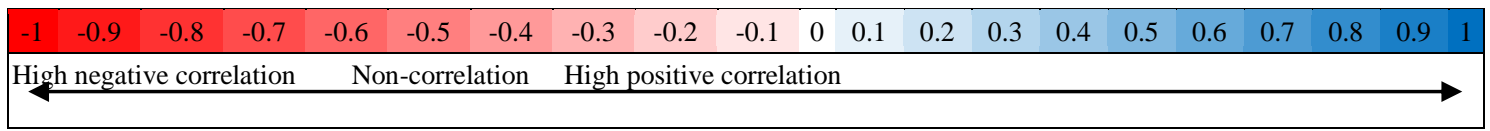

1: Number of pods with one seed; 2: Number of pods with two seeds; 3 : Number of pods with three seeds; 4 : Number of pods with four seeds; 5: Number of healthy pods in main branch; 6 : Number of healthy pods in lateral branch; 7: Total healthy pods per plant; 8: Total unhealthy pods per plant; 9: Number of seeds per pod; 10: Number of seeds per plant; 11: 100-seed weight; 12: Grain yield; 13: Biological yield; 14: Harvest index; 15: Seed oil content; 16: Seed protein content; 17: Abnormality percent

\section{Regression models of morphological and yielding traits with abnormality percent}

Number of pods with one-four seeds

According to Table 5, it was founded that regression between abnormality percent and number of pods with one-four seeds was significant for number of pods with two, three, and four seeds. Results showed that the $\mathrm{R}^{2}$ coefficient was obtained 49.32, 36.63, and $3.47 \%$ for number of pods with two, three, and four seeds, respectively. Figure 2 showed the distribution of points around regression line, according to results, the equation was obtained " $y=-0.3523 \mathrm{X}+33.1$ " between abnormality percent as depended variable and number of pods with two seeds as the independent variable. Also, this equation was obtained for number of pods with three and four seeds " $y=-0.3083 X+$ 
27.245 " and " $y=-0.0059 X+0.5492$ ", respectively. According to results, the means of number of pods with one seed, number of pods with two seeds, number of pods with three seeds, and number of pods with four seeds obtained 12.05, 29.17, 23.80, and 0.48, respectively (Table 6).

\section{Number of healthy pods}

The number of healthy pods in the main and lateral branch and per plant affected by abnormality percent at $1 \%$ statistically level (Table 5). The total healthy pods reduced by the increase of abnormality percent. The equation of regression for number of healthy pods in main and lateral branch and per plant were " $\mathrm{y}=-0.2842 \mathrm{X}+32.04$ ", “y $=-0.3736 \mathrm{X}+40.876 "$, and " $\mathrm{y}=-0.655 \mathrm{X}+72.677$ ", respectively (Fig. 2). The means of number of healthy pods in the main and lateral branch and per plant were 28.86, 36.70, and 65.36, respectively (Table 6).

Table 5. Analysis of regression for morphological, yield and yield components traits of soybean

\begin{tabular}{c|c|c|c|c|c|c|c|c|c}
\hline & & \multicolumn{7}{|c}{ Mean square (MS) } \\
\hline S.O.V & df & $\begin{array}{c}\text { Number of } \\
\text { pods with } \\
\text { one seed }\end{array}$ & $\begin{array}{c}\text { Number of } \\
\text { pods with } \\
\text { two seeds }\end{array}$ & $\begin{array}{c}\text { Number of } \\
\text { pods with } \\
\text { three seeds }\end{array}$ & $\begin{array}{c}\text { Number of } \\
\text { pods with } \\
\text { four seeds }\end{array}$ & $\begin{array}{c}\text { Number of } \\
\text { healthy pods in } \\
\text { the main } \\
\text { branch }\end{array}$ & $\begin{array}{c}\text { Number of } \\
\text { healthy } \\
\text { pods in the } \\
\text { lateral } \\
\text { branch }\end{array}$ & $\begin{array}{c}\text { Total } \\
\text { healthy } \\
\text { pods per } \\
\text { plant }\end{array}$ & $\begin{array}{c}\text { Total } \\
\text { unhealthy } \\
\text { pods per } \\
\text { plant }\end{array}$ \\
\hline Regression & 1 & $13.6 \mathrm{~ns}$ & $33555^{* *}$ & $24922^{* *}$ & $2377.5^{*}$ & $24176^{* *}$ & $15952^{* *}$ & $27436^{* *}$ & $44738^{* *}$ \\
\hline Residual & 113 & 602.0 & 305 & 382 & 585.7 & 388 & 461 & 359 & 206 \\
\hline $\begin{array}{c}\text { R-square } \\
(\%)\end{array}$ & - & 0.00 & 49.32 & 36.63 & 11.01 & 35.53 & 23.44 & 40.32 & 65.75 \\
\hline $\begin{array}{c}\text { S.O.V } \\
\text { df }\end{array}$ & $\begin{array}{c}\text { Number of } \\
\text { seeds per } \\
\text { pod }\end{array}$ & $\begin{array}{c}\text { Number of } \\
\text { seeds per } \\
\text { plant }\end{array}$ & $\begin{array}{c}\mathbf{1 0 0 - s e e d} \\
\text { weight }\end{array}$ & Grain yield & Biological yield & $\begin{array}{c}\text { Harvest } \\
\text { index }\end{array}$ & $\begin{array}{l}\text { Seed oil } \\
\text { content }\end{array}$ & $\begin{array}{c}\text { Seed } \\
\text { protein } \\
\text { content }\end{array}$ \\
\hline Regression & 1 & $40007 * *$ & $31547^{* *}$ & $31482^{* *}$ & $55615^{* *}$ & $42027^{* *}$ & $58349^{* *}$ & $17068^{* * *}$ & $1374.6 \mathrm{~ns}$ \\
\hline Residual & 113 & 248 & 323 & 324 & 110 & 230 & 86 & 451 & 590 \\
\hline $\begin{array}{c}\text { R-square } \\
(\%)\end{array}$ & - & 58.8 & 46.37 & 46.27 & 81.74 & 61.77 & 85.76 & 25.09 & 2.02 \\
\hline
\end{tabular}

Table 6. The average yield and yield components of traits in 120 experimental farms

\begin{tabular}{c|c|c|c}
\hline Variables & Average & Variables & Average \\
\hline Number of pods with one seed & 12.05 & Number of seeds per plant & 143.42 \\
Number of pods with two seeds & 29.17 & 100-seed weight (g) & 18.57 \\
Number of pods with three seeds & 23.80 & Grain yield (kg.ha-1) & 2716 \\
Number of pods with four seeds & 0.48 & Biological yield (kg.ha-1) & 8900.31 \\
Number of healthy pods in the main branch & 28.86 & Harvest index (\%) & 29.55 \\
Number of healthy pods in the lateral branch & 36.70 & Seed oil content (\%) & 19.11 \\
Total healthy pods per plant & 65.36 & Seed protein content (\%) & 36.22 \\
Total unhealthy pods per plant & 10.33 & Abnormality percent (\%) & 11.15 \\
Number of seeds per pod & 2.12 & & \\
\hline
\end{tabular}



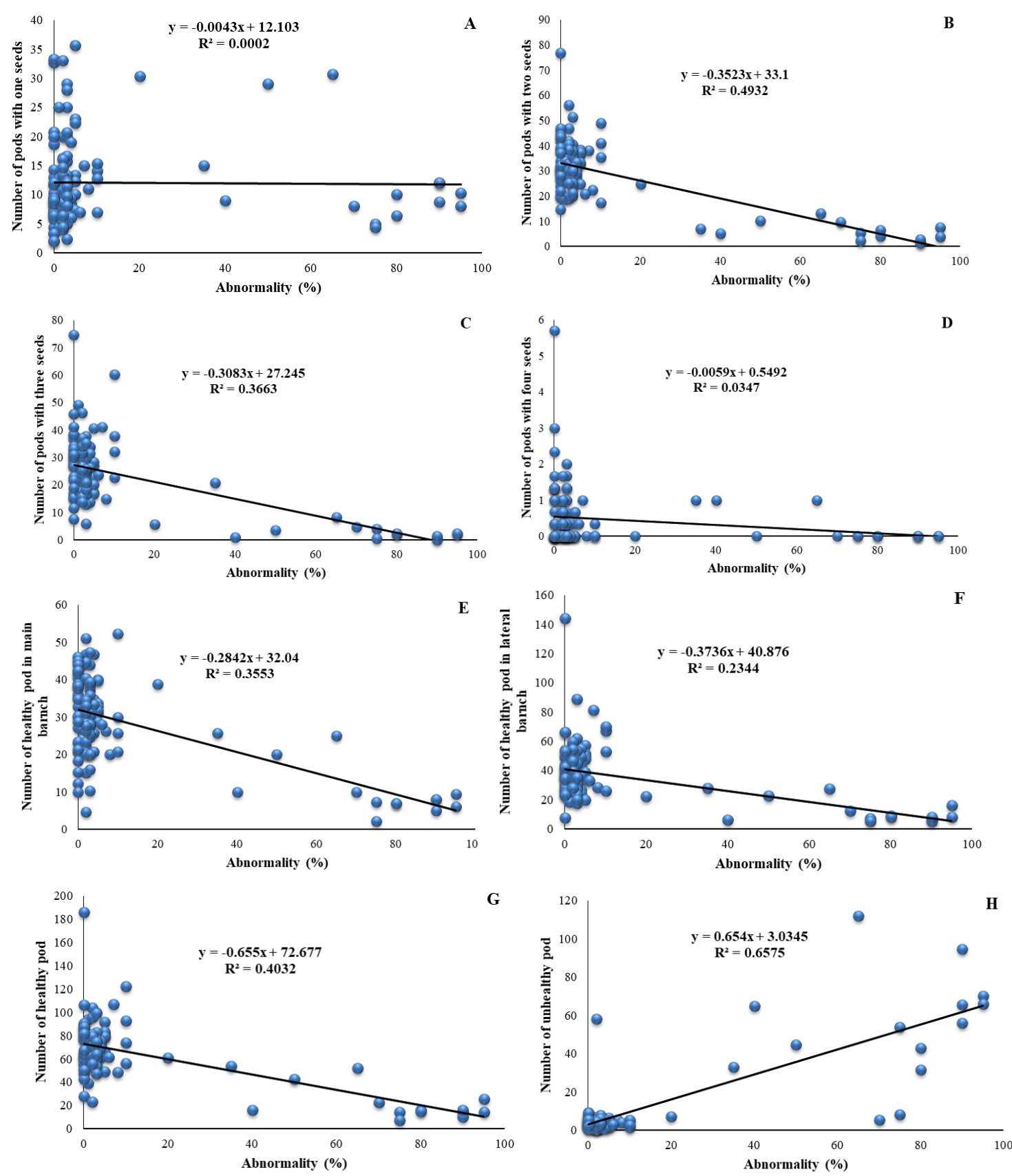

Figure 2. Regression curve between abnormality percent (as dependent variable) with number pods with one $(A)$, two $(B)$, three $(C)$, and four seeds $(D)$, number of healthy pod in main branch $(E)$, number of healthy pod in lateral branch $(F)$, number of healthy pods $(G)$, and number of unhealthy pods $(H)$ (as independent variables)

\section{Number of unhealthy pods}

According to the results of Table 5, the number of unhealthy pods affected by abnormality percent, $95 \%$ of the variation in the number of unhealthy pods is justified by abnormality percent. The equation of regression was " $y=0.654 \mathrm{X}+3.0345$ " between abnormality percent as dependent variable and the number of unhealthy pods as the independent variable (Fig. 2). The range of the number of unhealthy pods observed 
0.33- 70 unhealthy pods and the mean obtained 10.33 (Table 6). In unhealthy pod, the formation of pod occurs and even the seed forms inside it, but the pod does not have the ability to harvest. But in abnormality the pod is absurd (see Fig. 1).

\section{Number of seed}

There was a negative and curve-linear relationship between number of seeds per pod and plant with abnormality percent. $\mathrm{R}^{2}$ was obtained 58.8 and $46.4 \%$, respectively, and the equation was " $\mathrm{y}=-0095 \mathrm{X}+2.2302$ " and " $\mathrm{y}=-1.6544 \mathrm{X}+161.88$ " between abnormality percent as dependent variable and number of seed per pod and plant as independent variables (Fig. 3). The means of traits achieved 2.13 and 143.42 seeds per pod and plant, respectively (Table 6 ).

\section{0-seed weight}

There was a negative and curve-linear relationship between 100-seed weight with abnormality percent, and $\mathrm{R}^{2}$ was obtained $46.27 \%$, and the equation was " $\mathrm{y}=-0672 \mathrm{X}+$ 19.327 " between abnormality percent as the dependent variable and 100-seed weight as the independent variable. For farmer production, highest, lowest and means of 100-seed weight were 22.3, 10 and $18.57 \mathrm{~g}$, respectively (Table 6).

\section{Grain yield}

The farmers' average yield of soybean crops was $2716 \mathrm{~kg} \cdot$ ha $^{-1}$ (Table 6). There was a negative and curve-linear relationship between grain yield with abnormality percent, and $\mathrm{R}^{2}$ was obtained $85.76 \%$, and the equation of regression was " $\mathrm{y}=-29.628 \mathrm{X}+$ 3046.1 " between abnormality percent as depended variable and grain yield as the independent variable (Fig. 3). Also, the range of grain yield was obtained between 100 to $3578 \mathrm{~kg} \cdot \mathrm{ha}^{-1}$.

\section{Biological yield}

There was a negative and significant regression relationship between biological yields with abnormality percent (Table 5). The equation of regression was " $\mathrm{y}=-52.12 \mathrm{X}$ +9481.8 " between abnormality percent as dependent variable and biological yield as independent variable with $\mathrm{R}^{2}=61.77 \%$ (Fig. 3). The average of the trait was 8900.31 kg.ha- ${ }^{-1}$ (Table 6).

\section{Harvest index}

There was a negative and curve-linear relationship between harvest index with abnormality percent, and $\mathrm{R}^{2}$ was obtained $85.76 \%$, and the equation was " $\mathrm{y}=-2608 \mathrm{X}+$ 32.466 " between abnormality percent as dependent variable and harvest index as the independent variable. The average of the trait was $29.55 \%$ (Table 6).

\section{Seed oil content}

Results of regression analysis showed that the regression model was significant for the seed oil content and abnormality percent $(P \leq 0.01)$ (Table 5$)$. The equation of regression was " $\mathrm{y}=-0.0368 \mathrm{X}+19.528$ " between abnormality percent as dependent variable and seed oil content as independent variable, with $\mathrm{R}^{2}=25.09 \%$ (Fig. 3). The highest, lowest and means of the trait were $23.4,13$, and $19.11 \%$, respectively (Table 6). 

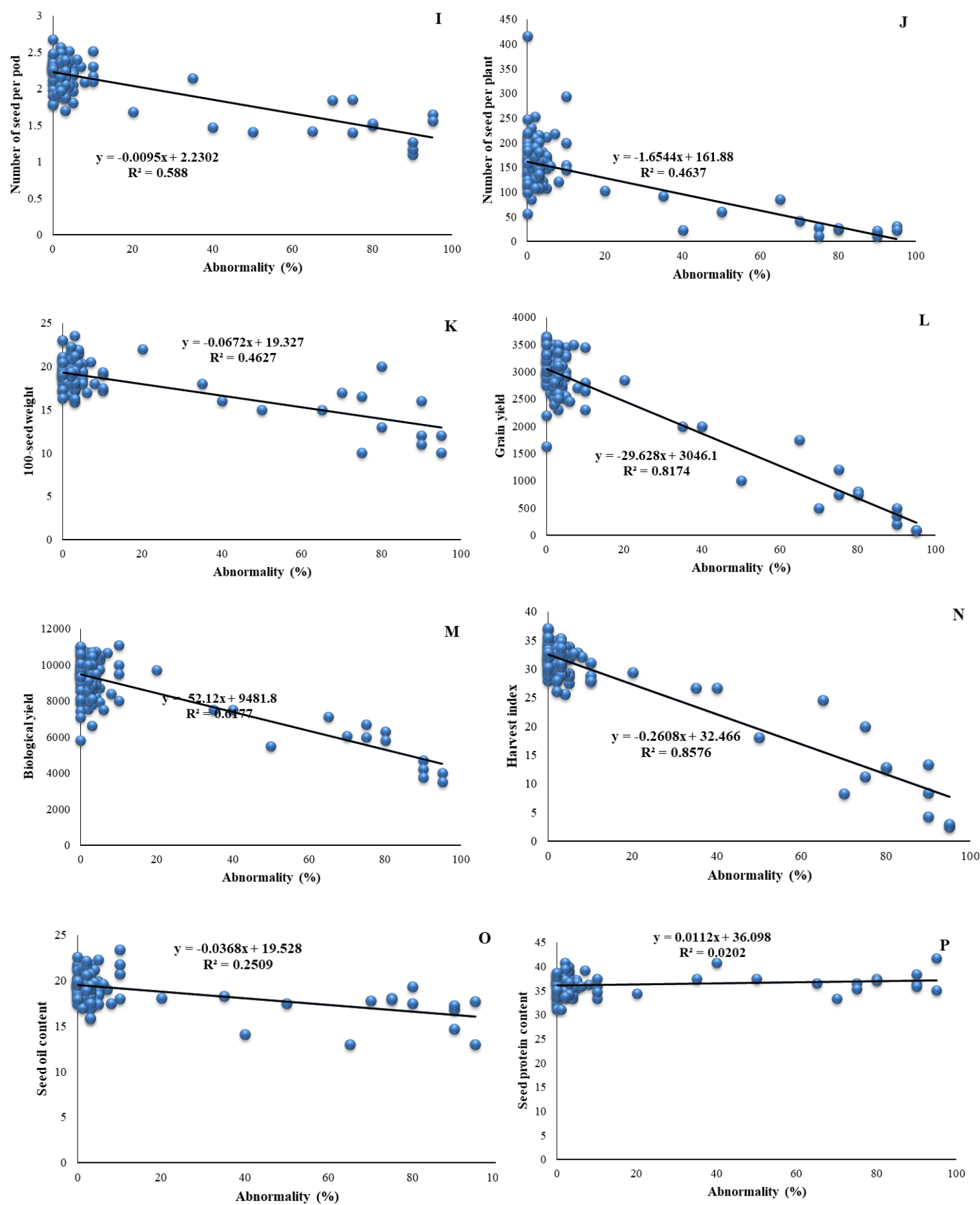

Figure 3. Regression curve between abnormality percent (as dependent variable) with number of seeds per pod (I), number of seeds per plant $(J), 100$-seed weight $(K)$, grain yield $(L)$, biological yield $(M)$, harvest index $(N)$, seed oil content $(O)$, and seed protein content $(P)($ as the independent variables)

\section{Seed protein content}

Results of regression analysis showed that the regression model was non-significant for the seed protein content and abnormality percent (Table 5). The equation of regression was " $\mathrm{y}=-0.0112 \mathrm{X}+36.098$ " between abnormality percent as dependent 
variable and seed protein content as independent variable, with $\mathrm{R}^{2}=2.09 \%$ (Fig. 3). The highest, lowest and means of the trait were $41.7,31.1$, and $36.22 \%$, respectively (Table 6).

\section{Regression models of meteorological data with abnormality percent}

All collected meteorological data included temperature, minimum and maximum of relative humidity, rainfall, the total number of rainy days, evaporation, wind speed, and etc for the R1-R7 growing stage were analyzed. From the presented data, three traits such as number of days with temperature above 25 and $28^{\circ} \mathrm{C}$ and also, number of days with temperature above $25{ }^{\circ} \mathrm{C}$ ( 5 days before and 10 days after flowering) were regression analyzed (Fig. 4). There was a negative and curve-linear relationship between abnormality percent (as the dependent variable) with number of days with temperature above 25 and $28{ }^{\circ} \mathrm{C}$. The equation of regression were " $\mathrm{y}=-0.0411 \mathrm{X}+$ 14.337 " and " $\mathrm{y}=-0.0142 \mathrm{X}+1.1587$ " between abnormality percent as dependent variable and number of days with temperature above 25 and $28{ }^{\circ} \mathrm{C}$ as independent variables (Fig. 4).
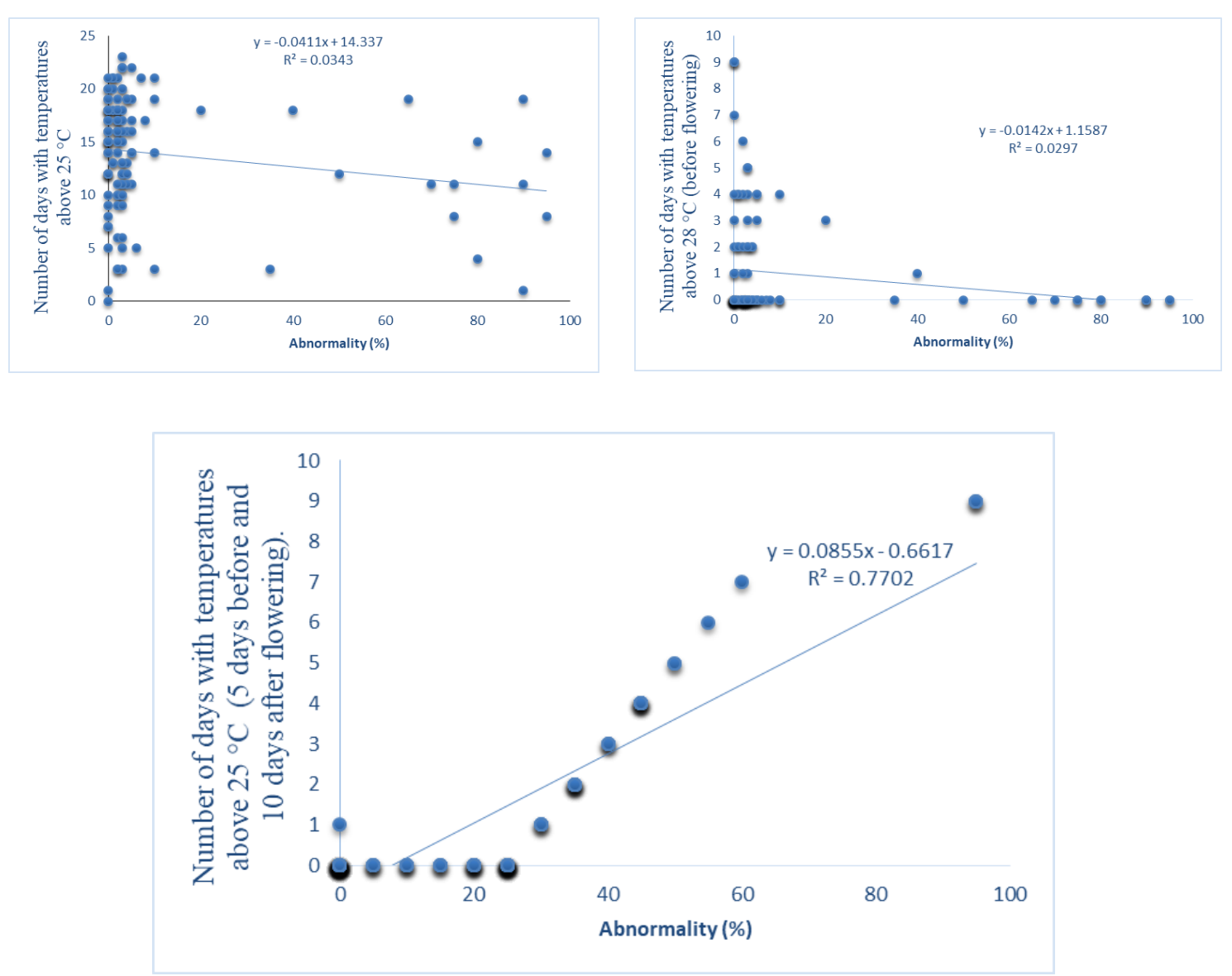

Figure 4. Regression curve between abnormality percent (as the dependent variable) with number of days with temperature above $25^{\circ} \mathrm{C}$, number of days with temperature above $28^{\circ} \mathrm{C}$, and number of days with temperature above $25^{\circ} \mathrm{C}$ (5 days before and 10 days after flowering) (as the independent variable) 
Positive and significant regression relationship between the temperature at the flowering stage (number of days with temperature above $25^{\circ} \mathrm{C}$ at 5 days before and 10 days after flowering) with the abnormality percent was observed. In other words, increasing the number of days with temperatures above $25^{\circ} \mathrm{C}$ in the flowering stage was observed more abnormality percent (Fig. 4). The equation of regression was " $y=$ $0.0855 \mathrm{X}-0.06617$ " between abnormality percent as dependent variable and number of days with temperature above $25^{\circ} \mathrm{C}$ in the flowering stage as the independent variable $\left(\mathrm{R}^{2}=77.02 \%\right)$ (Fig. 4).

\section{Discussion}

The results of simple correlation coefficients showed that there was a significant and positive correlation between yield and yield components as well as seed oil content (Table 4). With improved growth parameters and yield, components increased seed yield, biological yield, and harvest index. On the other hand, because the growth conditions are favorable for the plant, the seed oil content also increased. In the current study, grain yield had a positive and significant correlation with yield components such as number of seeds, number of pods, number of healthy pods per plant, 100-seed weight, biological yield, and seed oil content (Table 4). These results were supported by the results of Sedghi and Amanpour-Balaneji (2010) and El-Badawy and Mehasen (2012). Improving seed yield is still the priority to vegetable soybean breeders. However, seed yield is a function of several yield components including number of pods per plant, seeds per pod, plant height, node position and number per plant and seed size ( $\mathrm{Li}$ et al., 2013). The relationship between yield and yield components has been extensively studied in grain soybean and is used as a tool in cultivar selection by many researchers (Arshad et al., 2006). For example, more pods per plant and seeds per pod of soybean frequently have shown highest positive correlation with seed yield and thus are the most used criteria to improve seed yield in selection program (Showkat and Tyagi, 2010). Machikowa and Laosuwan (2011) stated that the correlation of particular trait with other traits contributing to seed yield is important in the indirect selection of genotypes for higher yield.

Variability in yield among crop species and cultivars of the same species is due to genetic potential and environmental conditions (Zhang et al., 2016; Negrao et al., 2017). The requirements of the plant are different in each growth stages and their sensitivity to environmental parameters can also be different in each variety of any crop (Farre et al., 2002; Blum, 2018). Growth, development, and yield of soybeans depend on the genetic potential of a cultivar and its interaction with the environmental conditions. In a field situation, nature provides the major portion of the environmental influence on soybean development and yield (Carvalho et al., 2017). The period of emergence to flowering is very important in soybean and the variations of it can determine the potential of the plant for entry to reproductive growth stage. In fact, the reaction of varieties depends on their maturity group, but their growth type can modify their behavior in stress condition (Raeisi, 2015). Fuganti-Pagliarin et al. (2017) showed that plants can modulate the metabolism in response to environmental circumstance by targeting different mechanisms, aiming for survival and keep productivity. In our study, in investigated the role of pod abnormality incidence on yield and yield components of soybeans and it determined the relationship between parameters, the $\mathrm{R}^{2}$ coefficient was obtained 0.87 between abnormalities with seed yield, pod abnormality had negative effects on yield 
components. Ray et al. (2012) examined the trends in crop yields for four key global crops: maize, rice, wheat, and soybeans. Although yields continue to increase in many areas, they find that across $24-39 \%$ of maize, rice, wheat, and soybean growing areas, yields never improve, stagnate or collapse. This result underscores the challenge of meeting increasing global agricultural demands. Bhatia et al. (2008) suggested that conservation of rainfall and drought-resistant varieties in low rainfall regimes; and alleviation of water-logging and use of water-logging tolerant varieties in high rainfall regimes will be the essential components of improved technologies aimed at reducing the yield gaps of soybean. Harvesting of excess rainfall during the season and its subsequent use as supplemental irrigation would further help in increasing crop yields at most locations (Bhatia et al., 2008). For reduction of the yield gap, it proposes to use local agronomic information obtained from the literature, surveys, international institutions, government agencies, or experts. Increasingly global databases with sowing and harvesting dates are becoming available (Bondeau et al., 2007; Waha et al., 2012). In the current study, the abnormality percent (dysfunction syndrome in the R3 stage of soybean growth) was affected by yield and yield components as well as the amount of oil and protein of seeds. In general, the improvement of the average traits resulted in a reduction in the abnormality percent. In other words, when agronomical and environmental conditions were favorable for soybean growth, the abnormality percent also decreased. The results obtained from Figure 2 showed that by increasing number of unhealthy pods, the abnormality percent was significantly increased. On the other hand, increasing the number of healthy pods led to a reduction in the abnormality percent. The results of the correlation coefficient (Table 4) and regression analysis (Table 5) are consistent in the case of the relationship between the number of healthy and unhealthy pods with the abnormality percent.

Temperature, defined as the energy state of an object, is one of the principal controls over plant distribution and productivity. It has large effects on physiological activity at all spatial and temporal scales (Sage and Kubien, 2007) and has an influence on the time course of crop development. Time course of crop development, the ontogeny, is a continuity of the vegetative, the reproductive, the grain filling or maturation phases through which a crop completes one life cycle (Tacarindua, 2013). In the current experiment, the results showed that among the environmental factors, temperature (especially high temperature) has a significant effect on the abnormality percent. According to Figure 4, the temperature above $25^{\circ} \mathrm{C}$ in the flowering time range ( 5 days before and 10 days later, equivalent to $\mathrm{R} 3$ growth stage) has increased effects on the abnormality percent. By increasing the number of more days in this growth stage increased the number of unhealthy pods. The rise in temperature above the optimum with negative impacts on plants is known as heat stress (Zrobek-Sokolnik, 2012) and is among the most commonly encountered stress factors, acting either independently or in combination with drought stress (Mittler, 2006; Kotak et al., 2007). With the current trend in surface temperature due to global warming, more extreme episodes of heat stress are likely to occur, thereby causing adverse impacts on crop yield.

In previous studies, increasing mean air temperature resulted in smaller soybean seeds (Heineman et al., 2006; Thomas et al., 2010) increased seed size or had no effect on the seed size (Sionit et al., 1987). In terms of seed yield, increasing temperature resulted in decreased yield (Heineman et al., 2006), increased yield (Sionit et al., 1987) slightly affected the yield (Ferris et al., 1999) or did not affect the yield of soybean (Zheng et al., 2002). On the other hand, increasing mean air temperature up to $32.5^{\circ} \mathrm{C}$ 
resulted in decreased total biomass in soybean (Tacarindua, 2013). Similarly, plants were grown under high mean air temperature up to $34{ }^{\circ} \mathrm{C}$ from 10 days after sowing (DAS) to maturity had less total biomass than the control (Koti et al., 2007). The magnitude of heat stress is known to depend upon the intensity (temperature in degrees), duration, the rate of increase in temperature (Wahid et al., 2007) and the stage of crop development (Prasad et al., 2008) with the reproductive stage being more sensitive than the vegetative. Heat stress event during pollination, for example, can severely reduce yield even when the seasonal average is within a favorable range (Long and Ort, 2010). In the present study, similar results were obtained.

Plants are generally exposed to multiple environmental stress, with drought and heat stress representing an excellent example of two different abiotic stress conditions that occur simultaneously in the field (Mittler, 2006). They are between the two most important environmental factors influencing crop growth, development and yield processes (Prasad et al., 2011). Despite their simultaneous occurrence, these two stresses are usually studied independently (Prasad et al., 2008) although their combined effects may be different from the effects when applied independently (Mittler, 2006).

Higher detrimental effects of high temperature and drought combined as compared to their effects separately have been reported for yield (Prasad et al., 2011; Pradhan et al., 2012), aboveground biomass (Shah and Paulsen, 2003; Prasad et al., 2011), grain size (Shah and Paulsen, 2003) and grain number (Prasad et al., 2011). Similar effects were reported for photosynthesis (Shah and Paulsen, 2003), water relations (Grigorova et al., 2011) and leaf chlorophyll content (Prasad et al., 2011).

\section{Conclusion}

The results of investigated of 120 farms showed that the abnormality percent (dysfunction syndrome) significantly affects grain yield. In some cases, resulted in a $30 \%$ reduction in grain yield. The results showed that there was a positive and significant correlation between yield and yield components as well as seed oil content. The results of analyzing the agronomic and climatic data showed that by improving the average of growth and yield traits of soybean, the damage of pod abnormality was reduced. In other words, there was a negative and significant relation between functional traits and abnormality percent. But, the abnormality percent increased by increasing the number of unhealthy pods. In general, among environmental and agronomic factors, the number of days higher than $25^{\circ} \mathrm{C}$ at flowering stage $(5$ days before and 10 days after flowering) had a significantly positive correlation with the abnormality percent. The increase in this numbers of days during this stage has led to a sharp increase in the pod abnormality. It can be concluded that crop management such as suitable planting date, cultivation of tolerant genotype, irrigation management especially at flowering stage, nutrition management, and others, can reduce the severity of the abnormality percent.

\section{REFERENCES}

[1] Agricultural Jihad Organization of Golestan Province (2016): Report on the status of disruption of dysfunction syndrome in the R3 stage of soybean growth during 2007-2015 in Golestan Province. - Annual Report (in Persian). 
[2] Arshad, M., Alin. N., Ghafoor, A. B. (2006): Character correlation and path coefficient in soybean Glycine max (L.) Merrill. - Pakistan Journal Botany, Karachi 38(1): 121-130.

[3] Bezerra, A. R. G., Sediyama, T., Cruz, C. D., Silva, C. S., Silva, A. F., Rosa, D. P., Dias, L. A. S. (2016): Productivity and quality of soybean seeds of determinate and indeterminate growth type desiccated on pre-harvest. - Australian Journal of Crop Science 10(5): 693-700.

[4] Bhatia, V. S., Singh, P., Wani, S. P., Rao, A. K., Srinivas, K. (2006): Yield gap analysis of soybean, groundnut, pigeon pea and chickpea in India using simulation modeling. Global Theme on Agroecosystems Report no. 31.

[5] Bhatia, V. S., Singh, P., Wani, S. P., Chauhan, G. S., Rao, A. K., Mishra, A. K., Srinivas, K. (2008): Analysis of potential yields and yield gaps of rainfed soybean in India using CROPGRO-Soybean model. - Agricultural and Forest Meteorology 148(8): 1252- 1265.

[6] Blum, A. (2018): Plant breeding for stress environments. - CRC Press, Boca Raton.

[7] Bondeau, A., Smith, P. C., Zaehle, S., Schaphoff, S., Lucht, W., Cramer, W., Gerten, D., Lotze-Campen, H., Mülle, C., Reichstein, M., Smith, B. (2007): Modelling the role of agriculture for the 20th century global terrestrial carbon balance. - Global Change Biology 13(3): 679- 706.

[8] Carvalho, C. F., Virgílio, G. U., Clovis, A. S., Cileide, M. M. C. (2017): Physiological quality of soybean seed cultivars (Glycine $\max$ (L.) Merr) with different maturity groups. - Research Journal of Seed Science 10: 59-72.

[9] El-Badawy, M. E. M., Mehasen, S. A. S. (2012): Correlation and path coefficient analysis for yield and yield components of soybean genotypes under different planting density. Asian Journal of Crop Science 4(4): 150-158.

[10] Faraji, A., Raessi, S. (2015): Dysfunction syndrome in podding of soybean. - Golestan Province Agricultural and Natural Resources Research Center, Iran (in Persian).

[11] Farre, I., Robertson, M. J., Walton, G. H., Asseng, S. (2002): Simulating phonology and yield response of canola to sowing date in Western Australia. - Australian Journal of Agricultural Research 53: 1155- 1164.

[12] Ferris, R., Wheeler, T. R., Ellis, R. H., Hadley, P. (1999): Seed yield after environmental stress in soybean grown under elevated $\mathrm{CO}_{2}$. - Crop Science 39: 710-718.

[13] Firake, D. M., Behere, G. T., Chandra, S. (2016): An environmentally benign and costeffective technique for reducing bird damage to sprouting soybean seeds. - Field Crops Research 188: 74-81.

[14] Fuganti- Pagliarini, R., Ferreira, L. C., Rodrigues, F. A., Molinari, H. B., Marin, S. R., Molinari, M. D., Marcolino-Gomes, J., Mertz-Henning, L. M., Farias, J. R., de Oliveira, M. C., Neumaier, N. (2017): Characterization of soybean genetically modified for drought tolerance in field conditions. - Frontiers in Plant Science 8: 448-453.

[15] Gallaher, R. N., Weldon, C. O., Futral, J. G. (1975): An aluminum block digester for plant and soil analysis. - Soil Science Society of America Proceedings 39: 803-806.

[16] Grigorova, B., Vaseva, I., Demirevska, K., Feller, U. (2011): Combined drought and heat stress in wheat: changes in some heat shock proteins. - Biol. Plant 55: 105-111.

[17] Hambleton, L. G. (1977): Semiautomated method for simultaneous determination of phosphorus, calcium and crude protein in animal feeds. - Journal of American Oil Chemists Society 60: 845-852.

[18] Heineman, A. B., Maia, A. H. H., Dourado-Heto, D., Ingram, K. T., Hoogenboom, G. (2006): Soybean (Glycine max (L.) Merr) growth and development response to $\mathrm{CO}_{2}$ enrichment under different temperature regimes. - Europ. J. Agron. 24: 52-61.

[19] Ittersum, M. K., Cassman, K. G., Grassini, P., Wolf, J., Tittonell, P., Hochman, Z. (2013): Yield gap analysis with the local global relevance-A review. - Field Crops Reseach 143: 4-17.

[20] Kotak, S., Larkindale, J., Lee, U., Von Koskull-Doring, P. (2007): Complexity of the heat stress response in plants. - Curr. Opin. Plant Biol. 10: 310-316. 
[21] Koti, S., Reddy, K. R., Reddy, V. R., Kakani, V. G., Zhao, D., Gao, W. (2007): Effects of carbon dioxide, temperature and ultraviolet-B radiation and their interactions on soybean (Glycine $\max$ L.) growth and development. - Environ. Exp. Bot. 60: 1-10.

[22] Kumagai, E., Sameshima, R. (2014): Genotypic differences in soybean yield responses to increasing temperature in a cool climate are related to maturity group. - Agric. For. Meteorol. 199: 265-272.

[23] Lamastus, F. E., Shaw, D. R. (2005): Comparison of different sampling scales to estimate weed populations in three soybean fields. - Precision Agriculture 6(3): 271-280.

[24] Li, Y. S., Du, M., Zhang, Q. Y., Hashemi, M., Liu, X. B., Hebert, S. J. (2013): Correlation and path coefficient analysis for yield components of vegetable soybean in northeast China. - Legume Research 36: 284-288.

[25] Licker, R., Johnston, M., Foley, J. A., Barford, C., Kucharik, C. J., Monfreda, C., Ramankutty, N. (2010): Mind the gap: how do climate and agricultural management explain the 'yield gap' of croplands around the world? - Global Ecology and Biogeography 19(6): 769- 782.

[26] Long, S. P., Ort, D. R. (2010): More than taking the heat: crops and global changes. Curr. Opin. Plant Biol. 13: 241-248.

[27] Machikowa, T., Laosuwan, P. (2011): Path coefficient analysis for yield of early maturing soybean. - Songklanakarin Journal of Science and Technology 33(4): 365-368.

[28] Mittler, R. (2006): Abiotic stress, the field environment and stress combination. - Trends Plant Sci. 11: 15-19.

[29] Negrão, S., Schmöckel, S. M., Tester, M. (2017): Evaluating the physiological responses of plants to salinity stress. - Annals of Botany 119(1): 1-11.

[30] Ohnishi, S., Miyoshi, T., Shirai, S. (2010): Low-temperature stress at different flower developmental stages affects pollen development, pollination, and pod set in soybean. Environmental and Experimental Botany 69(1): 56-62.

[31] Ospanbayev, Z. H. O., Kurmanbayeva, M. S., Abdukadirova, Z. H. A., Doszhanova, A. S., Nazarbekova, S. T., Inelova, Z. A., Ablaikhanova, N. T., Kenenbayev, S. B., Musina, A. S. (2017): Water use efficiency of rice and soybean under drip irrigation with mulch in the south-east of Kazakhstan. - Applied Ecology and Environmental Research 15(4): 1581-1603.

[32] Pipolo, A. E., Sinclair, T. R., Camara, G. M. S. (2004): Effects of temperature on oil and protein concentration in soybean seeds cultured in vitro. - Annals of Applied Biology 144: 71-76.

[33] Pradhan, G. P., Prasad, P. V. V., Fritz, A. K., Kirkham, M. B., Gill, B. S. (2012): Effects of drought and high-temperature stress on synthetic hexaploid wheat. - Funct. Plant Biol. 39: 190-198.

[34] Prasad, P. V. V., Pisipati, S. R., Mutava, R. H., Tuinstra, M. R. (2008): Sensitivity of grain sorghum to high-temperature stress during reproductive development. - Crop Sci. 48: 1911-1917.

[35] Prasad, P. V. V., Pisipat, S. R., Momcilovic, I., Ristic, Z. (2011): Independent and combined effects of high temperature and drought stress during grain filling on plant yield and chloroplast EF-Tu expression in spring wheat. - J. Agron. Crop Sci. 197: 430441.

[36] Raeisi, S. (2015): Prediction of flowering occurrence in soybean in the north of Iran. Technology Tanaman (12): 392- 397 (in Persian).

[37] Rahimian, H., Hamdollah-Zadeh, A., Montazeri, M. (1995): Viruses associated with soybean pod set failure syndrome in Iran. - J. Plant Pathol. 32: 70-71.

[38] Ray, D. K., Ramankutty, N., Mueller, N. D., West, P. C., Foley, J. A. (2012): Recent patterns of crop yield growth and stagnation. - Nature Communications 3: 1293-1306.

[39] Sage, R. F., Kubien, D. S. (2007): The temperature response of C3 and C4 photosynthesis. - Plant Cell Environ. 30: 1086-1106. 
[40] Saryoko, A., Homma, K., Lubis, I., Shiraiwa, T. (2017): Plant development and yield components under a tropical environment in soybean cultivars with temperate and tropical origins. - Plant Production Science 20(4): 375-383.

[41] Sedghi, M., Amanpour-Balaneji, B. (2010): Sequential path model for grain yield in soybean. - Not. Sci. Biol. 2: 104-109.

[42] Sentelhas, P. C., Battisti, R., Câmara, G. M. S., Farias, J. R. B., Hampf, A. C., Nendel, C. (2015): The soybean yield gap in Brazil-magnitude, causes and possible solutions for sustainable production. - The Journal of Agricultural Science 153(8): 1394- 1411.

[43] Shah, H. H., Paulsen, G. M. (2003): Interaction of drought and high temperature on photosynthesis and grain-filling of wheat. - Plant Soil 257: 219-226.

[44] Showkat, M., Tyagi, S. D. (2010): Correlation and path coefficient analysis of some quantitative traits in soybean (Glycine max 1. Merrill). - Res. J. Agric. Sci. 1(2): 102-106.

[45] Sionit, H., Strain, B. R., Flint, E. P. (1987): Interaction of temperature and $\mathrm{CO}_{2}$ enrichment on soybean: growth and dry matter partitioning. - Can. J. Plant Sci. 67: 5967.

[46] Tacarindua, C. R. P. (2013): Effects of increased temperature on growth and seed production of soybean. - Ph.D. Thesis of Kyoto University.

[47] Thomas, J. M. G., Boote, K. J., Pan, D., Allen, L. H. (2010): Elevated temperature delays onset of reproductive growth and reduces seed growth rate of soybean. - J. Agrocrop Sci. 1: 19-32.

[48] Thuzar, M., Puteh, A. B., Abdullah, N. A. P., Lassim, M. B. M., Jusoff, K. (2010): The effects of temperature stress on the quality and yield of soya bean [Glycine max L.) Merrill.]. - Journal of Agricultural Science 2(1): 172-179.

[49] Van Roekel, R. J., Purcell, L. C., Salmeron, M. (2015): Physiological and management factors contributing to soybean potential yield. - Field Crops Research 182: 86-97.

[50] Waha, K., Van Bussel, L. G. J., Müller, C., Bondeau, A. (2012): Climate-driven simulation of global crop sowing dates. - Global Ecology and Biogeography 21(2): 247259.

[51] Wahid, A., Gelani, S., Ashraf, M., Foolad, M. R. (2007): Heat tolerance in plants: An overview. - Environ. Exp. Bot. 61: 199-223.

[52] Yagoub, S. O., Ahmad, W. M. A., Mariod, A. A. (2012): Effect of urea, NPK, and compost on growth and yield of soybean (Glycine max L.) in the semi-arid region of Sudan. - ISRN Agronomy http://dx.doi.org/10.5402/2012/678124.

[53] Zhang, X., Wang, M., Wu, T., Wu, C., Jiang, B., Guo, C., Han, T. (2016): Physiological and molecular studies of staygreen caused by pod removal and seed injury in soybean. The Crop Journal 4(6): 435- 443.

[54] Zheng, S., Hakamoto, H., Yoshikawa, K., Furuya, T., Fukuyama, M. (2002): Influence of high night temperature on flowering and pod setting in soybean. - Plant Prod. Sci. 5(3): 215-218.

[55] Zrobek-Sokolnik, A. (2012): Temperature stress and Response of Plants. - In: Ahmad, P., Prasad, M. N. V. (eds.) Environmental Adaptations and Stress Tolerance of Plants in the Era of Climate Change. - Springer Science+Business Media, New York, pp. 113-134. 